\title{
Division of Group XVI Spiroplasmas into Subgroups
}

\author{
M. L. ABALAIN-COLLOC,${ }^{1 *}$ D. L. WILLIAMSON, ${ }^{2}$ P. CARLE, ${ }^{3}$ J. H. ABALAIN,${ }^{4}$ F. BONNET, ${ }^{3}$ \\ J. G. TULLY, ${ }^{5}$ M. KONAI, ${ }^{6}$ R. F. WHITCOMB ${ }^{6}{ }^{\text {J. M. MOVÉ }},{ }^{3}$ AND C. CHASTEL ${ }^{1}$ \\ Laboratoires de Bactériologie ${ }^{1}$ and Biochimie, ${ }^{4}$ Faculté de Médecine, 22 Avenue Camille Desmoulins, 29285 \\ Brest, and Laboratoire de Biologie Cellulaire et Moléculaire, Institut National de la Recherche Agronomique \\ et Université de Bordeaux II, 33883 Villenave d'Omon, ${ }^{3}$ France; Department of Anatomical Sciences, Health \\ Sciences Center, State University of New York, Stony Brook, New York 117942; Mycoplasma Section, \\ Laboratory of Molecular Microbiology, Frederick Cancer Research Center, National Institute of Allergy and \\ Infectious Diseases, Frederick, Maryland 21701 ${ }^{\text {; }}$ and Insect Biocontrol Laboratory, Plant Protection \\ Institute, Beltsville Agricultural Research Center, U.S. Department of Agriculture, \\ Beltsville, Maryland $20705^{6}$
}

\begin{abstract}
Some group XVI spiroplasmas, such as strains CC-1 (Spiroplasma cantharicola) and CB-1, are associated with cantharid beetles. Fifteen related but heterogeneous strains have been isolated from mosquitoes, other insects, and a flower in France and the United States. In the present study, these seventeen strains have been compared by deformation and metabolism inhibition serological tests, by one-dimensional protein sodium dodecyl sulfate-polyacrylamide gel electrophoresis, and by determination of the guanine-plus-cytosine content of their DNA. Five of the 17 strains were further compared by DNA-DNA hybridization and by restriction enzyme (EcoRI and HindIII) analysis of their DNA. On the basis of the resulting data, we propose that group XVI be subdivided into three subgroups. Subgroup XVI-I is represented by strain CC-1 (ATCC 43207) from a cantharid beetle in the United States, and strain MQ-6 from a wasp; subgroup XVI-2 is represented by strain CB-1 (ATCC 43208) from a cantharid beetle and two strains from mosquitoes, all in the United States; and subgroup XVI-3 is represented by strain Ar-1357 (ATCC 51126) and contains 11 strains from mosquitoes and 1 strain from a flower, all from the Savoy region of France.
\end{abstract}

Since the first isolation of spiroplasmas in 1971 (16), the genus Spiroplasma has continued to grow and currently contains many strains isolated from various insects, ticks, and plants. Serological techniques were first used for spiroplasma classification (26). Genomic and other molecular techniques were subsequently applied to this group of microorganisms (12). These tests include the guanine plus cytosine $(\mathrm{G}+\mathrm{C})$ content of DNA, genome size, DNA-DNA hybridization, DNA restriction endonuclease patterns, and polyacrylamide gel electrophoresis (PAGE) patterns of cell proteins (2). The current classification recognizes 24 groups of spiroplasmas $(9,18)$. A group $(12)$ is a cluster of spiroplasma strains that are serologically related, share 10 to $100 \%$ DNA-DNA homology, and possess a significant number of similar proteins by PAGE. Usually, but not always (11), all strains of groups have an identical $\mathrm{G}+\mathrm{C}$ content of their DNA (24).

Many groups are represented by one strain or by closely related strains (24). However, some groups are heterogeneous. For example, group I has been subdivided into eight subgroups on the basis of serological data, cell protein analysis, and genomic analysis $(2,18)$. Strains of some other heterogeneous groups (e.g., group IV) (1) are too closely related to warrant a subgroup designation.

Group XVI contains strains isolated in the United States (Maryland and Alabama) and in France (Savoy) from various insect species and a flower $(4-6,17,18)$. Preliminary serological studies (18) showed that group XVI was heterogeneous. We chose 17 group XVI strains for the present study. To define the taxonomic heterogeneity of these strains, reciprocal deformation (DF) and metabolism inhibition (MI) tests were performed, protein patterns of all strains were analyzed by one-dimensional PAGE, and five strains were

\footnotetext{
${ }^{*}$ Corresponding author.
}

selected for determination of the DNA restriction endonuclease patterns and the amount of DNA-DNA homology among them.

In this report, we present the results of the comparative serological and molecular studies of group XVI strains and propose that the group be subdivided into three subgroups.

\section{MATERIALS AND METHODS}

Origin of strains. Seventeen strains were studied. Five strains (CC-1, CB-1, MQ-6, ANP, and AEF-2) were collected in the United States, and the 12 other strains were collected in France. The hosts and geographic origins of the strains are given in Table 1 . Strain CC-1 was designated as the type strain of Spiroplasma cantharicola (21).

Culture media. The CC-1, CB-1, and MQ-6 strains were isolated in SM-1 medium (19). Strains ANP and AEF-2 were isolated in $\mathrm{M}_{1} \mathrm{M}_{2} \mathrm{M}_{3}$ media (17), and the strains collected in France were isolated in SP-4 medium (19). All the strains were triply cloned on M1D agar medium and then maintained at $30^{\circ} \mathrm{C}$ by passing a $10 \%$ inoculum every day into fresh medium. To provide a uniform source of inoculum, a $10-\mathrm{ml}$ batch culture of each strain was prepared and aliquoted in mid-logarithmic-growth phase into $0.5-\mathrm{ml}$ volumes in microtubes, which were stored at $-70^{\circ} \mathrm{C}$.

Serological tests. Antisera against the CC-1, CB-1, MQ-6, ANP, and Ar-1357 strains were prepared in rabbits by previously described techniques (26). Sera were inactivated at $56^{\circ} \mathrm{C}$ for $30 \mathrm{~min}$ and stored at $-20^{\circ} \mathrm{C}$. The 17 strains were compared serologically by using DF and MI tests, which have been described elsewhere (25).

Genomic analysis. The $\mathrm{G}+\mathrm{C}$ content of the DNA of the 17 strains was calculated from the melting temperature and the buoyant density $(\rho)$ as described previously (3).

PAGE of proteins. We used one-dimensional PAGE analysis in the presence of sodium dodecyl sulfate (SDS) to 
TABLE 1. Geographical and host origin of group XVI spiroplasmas

\begin{tabular}{llll}
\hline \multicolumn{1}{c}{ Strain $^{a}$} & Host & \multicolumn{1}{c}{ Binomial name } & $\begin{array}{c}\text { Geographical } \\
\text { origin }\end{array}$ \\
\hline CC-1 (ATCC 43207) & Beetle & Cantharis carolinus & Maryland \\
CB-1 (ATCC 43208) & Beetle & Cantharis bilineatus & Maryland \\
MQ-6 & Wasp & Monobia quadridens & Maryland \\
ANP & Mosquito & Anopheles punctipennis & Alabama \\
AEF-2 & Mosquito & Aedes fulvus/annulipes & Alabama \\
Ar-1357 (ATCC 51126) & Mosquito & Aedes cantans/vexans $/$ vexans & Savoy, France \\
Ar-1531 & Mosquito & Aedes cantans/vexans & Savoy, France \\
Ar-1569 & Mosquito & Aedes sticticus/vexans & Savoy, France \\
Ar-1528 & Mosquito & Aedes sticticus/vexans & Savoy, France \\
Ar-1548 & Mosquito & Aedes sticticus/vexans & Savoy, France \\
Ar-1549 & Mosquito & Aedes sticticus/vexans & Savoy, France \\
Ar-1550 & Mosquito & Savoy, France \\
Ar-1567 & Mosquito & Coquillettidia richiardii & Savoy, France \\
Ar-1537 & Mosquito & Savoy, France \\
Ar-1546 & Mosquito & Savoy, France \\
Ar-1570 & Mosquito & Sedes cinereus/geminus & Savoy, France \\
PI-30L & Plant (thistle) & Savoy, France \\
\hline
\end{tabular}

${ }^{a}$ Accession numbers from the American Type Culture Collection are given in parentheses.

examine the patterns of cellular proteins from the 17 isolates. The SDS-PAGE system consisted of a separating gel containing an exponential polyacrylamide gradient (15 to $20 \%$ ) with a 5\% stacking gel prepared according to the methods of Daniels et al. (7) and Mouches et al. (15).

DNA-DNA hybridization. DNA of strain CC-1, the representative strain of group XVI, was labeled by nick translation by using the nick translation kit (N 5000) from Amersham Corp. (Arlington Heights, Ill.) and $\left[{ }^{3} \mathrm{H}\right] \mathrm{dCTP}$ and hybridized with unlabeled DNA from strains CB-1, MQ-6, ANP, and Ar-1357. The percentages of hybridization were determined by the $S_{1}$ nuclease technique (8).

DNA hydrolysis by restriction enzymes. DNA of strains CC-1, CB-1, MQ-6, ANP, and Ar-1357 were hydrolyzed by EcoRI and HindIII restriction endonucleases purchased from Bethesda Research Laboratories, Inc. (Gaithersburg, Md.). The fragments were separated by agarose gel electrophoresis (1\%), revealed by ethidium bromide staining, and photographed in UV light with a Polaroid camera.

Temperature requirements. The temperature requirements of the group XVI spiroplasmas were studied in M1D medium. Twelve 10-fold dilution series of late-logarithmicphase cultures were prepared by using preincubated medium for each temperature. The growth was recorded daily for more than 40 days. Doubling times at $5,10,15,20,25,30,32$, 37,41 , and $43^{\circ} \mathrm{C}$ were determined by fitting the temperaturetime curves to logistic growth equations (13).

\section{RESULTS}

Serological tests. The results of DF and MI tests of the 17 strains (Table 2) permit comparison of group XVI strains. Strains AEF-2 and ANP from Alabama were similar or identical. Strains CB-1 and ANP were very closely related, since the twofold difference in their DF titers is within experimental error. Strains CC-1 and MQ-6 were relatively closely related, since their threefold MI separation was also within experimental error. On the other hand, strain Ar-1357 and other strains from Savoy were distinct from strains CC-1, CB-1, MQ-6, and ANP (differences of two to four dilutions in their DF and MI endpoints).

PAGE protein patterns. The banding patterns of cell proteins from the 17 strains are shown in Fig. 1. All the strains had approximately 30 visible protein bands. The molecular mass of the majority of proteins was between 18 and $67 \mathrm{kDa}$. Comparative analysis of the one-dimensional PAGE protein patterns indicated that all strains have many proteins in common. Nevertheless, protein differences among the strains could be identified. For example, a $21-\mathrm{kDa}$ protein was present in all strains, except for strains CC-1 and MQ-6; a $26-\mathrm{kDa}$ protein was absent in strains CC-1, MQ-6, and PI-30L; a 35-kDa protein was present only in strains CB-1, AEF-2, and ANP; and a $17-\mathrm{kDa}$ protein was missing in all strains from Savoy.

Genomic analysis. The $\mathrm{G}+\mathrm{C}$ content of the DNA of all spiroplasma group XVI strains was $(26 \pm 1) \mathrm{mol} \%$ (Table 3$)$.

DNA-DNA hybridization. Table 4 gives the percentage of hybridization between labeled CC-1 DNA and unlabeled DNAs of strains CB-1, MQ-6, ANP, and Ar-1357, as determined by analysis with $S_{1}$ nuclease. The percentage of homology between strains CC-1 and MQ-6 DNA was $100 \%$. The percentage of homology between strain CC-1 DNA and strains CB-1, ANP, and Ar-1357 DNAs was 61, 63, and 69\%, respectively.

Restriction enzyme patterns. The restriction enzyme patterns are shown in Fig. 2. DNA from strains CC-1, MQ-6, and Ar-1357 was each hydrolyzed by both EcoRI and HindIII; DNA from strains CB-1 and ANP was hydrolyzed by EcoRI but not by HindIII. In addition to their insensitivity to HindIII hydrolysis, strains CB-1 and ANP showed very similar EcoRI restriction patterns of DNA, providing further evidence that these two strains are closely related. Finally, the restriction patterns produced by EcoRI and HindIII digestion of strains CC-1, MQ-6, and Ar-1357 DNAs were very different.

Temperature ranges. Strain $\mathrm{CC}-1$ grew at 10 to $37^{\circ} \mathrm{C}$, with an optimum at $32^{\circ} \mathrm{C}$. The optimal doubling time was $2.6 \mathrm{~h}$. Strain CB-1, on the other hand, grew at 10 to $32^{\circ} \mathrm{C}$. The optimum was $30^{\circ} \mathrm{C}$, at which temperature the doubling time was $2.6 \mathrm{~h}$. Strain Ar-1357 grew at a range of 10 to $32^{\circ} \mathrm{C}$. The optimum temperature of growth was $30^{\circ} \mathrm{C}$, and the doubling time at that temperature was $3.4 \mathrm{~h}$. Strain MQ-6 had a temperature range of 10 to $37^{\circ} \mathrm{C}$, with an optimum at $32^{\circ} \mathrm{C}$. The optimal doubling time was found to be $2.5 \mathrm{~h}$. 
TABLE 2. Serological comparison of group XVI spiroplasmas by DF and MI tests

\begin{tabular}{|c|c|c|c|c|c|c|c|c|c|c|}
\hline \multirow{3}{*}{ Antigens } & \multicolumn{10}{|c|}{ Antiserum to: } \\
\hline & \multicolumn{2}{|c|}{ CC-1 } & \multicolumn{2}{|c|}{ CB-1 } & \multicolumn{2}{|c|}{ MQ-6 } & \multicolumn{2}{|c|}{ ANP } & \multicolumn{2}{|c|}{ Ar- 1357} \\
\hline & $\mathrm{DF}^{a}$ & $\mathrm{MI}^{b}$ & DF & MI & DF & MI & DF & MI & DF & MI \\
\hline CC-1 & 1,280 & 39,000 & $\mathrm{~N}^{c}$ & 162 & 320 & 13,000 & $\mathbf{N}$ & 162 & 80 & 162 \\
\hline MQ-6 & 320 & 4,374 & 40 & 1,458 & 1,280 & 118,000 & $\mathbf{N}$ & 1,458 & 160 & 1,458 \\
\hline CB-1 & 40 & 162 & 640 & 39,000 & 40 & 4,374 & 320 & 13,000 & 80 & 486 \\
\hline ANP & 40 & 162 & 640 & 13,000 & 20 & 486 & 640 & 39,000 & 320 & 486 \\
\hline AEF-2 & 40 & 162 & 640 & 13,000 & 20 & 486 & 640 & 39,000 & 320 & 486 \\
\hline Ar-1357 & 80 & 486 & 80 & 486 & 160 & 4,374 & 40 & 486 & 1280 & 118,000 \\
\hline Ar- 1528 & 40 & 4,374 & 20 & 4,374 & $\mathbf{N}$ & 1,458 & $\mathbf{N}$ & 486 & 2560 & 4,374 \\
\hline Ar- 1531 & 40 & 162 & 40 & 4,374 & $\mathrm{~N}$ & 4,374 & $\mathbf{N}$ & 486 & 2560 & 13,000 \\
\hline Ar- 1537 & 40 & 486 & $\mathrm{~N}$ & 39,000 & 160 & 39,000 & 40 & 39,000 & 2560 & 13,000 \\
\hline Ar-1546 & 20 & 1,458 & $\mathrm{~N}$ & 39,000 & 40 & 1,458 & 20 & 486 & 1280 & 13,000 \\
\hline Ar-1548 & 40 & 168 & 40 & 1,458 & 80 & 1,458 & $\mathbf{N}$ & 162 & 1280 & 13,000 \\
\hline Ar-1549 & $\mathbf{N}$ & 4,374 & 20 & 39,000 & 80 & 13,000 & $\mathrm{~N}$ & 4,374 & 1280 & 118,000 \\
\hline Ar -1550 & 40 & 1,458 & $\mathbf{N}$ & 4374 & 20 & 486 & $\mathbf{N}$ & 1,458 & 1280 & 39,000 \\
\hline $\mathrm{Ar}-1567$ & $\mathbf{N}$ & 486 & $\mathrm{~N}$ & 13,000 & 20 & 4,374 & $\mathrm{~N}$ & 486 & 1280 & 13,000 \\
\hline Ar- 1569 & $\mathbf{N}$ & 162 & $\mathbf{N}$ & 162 & $\mathbf{N}$ & 118,000 & $\mathbf{N}$ & 1,458 & 1280 & 39,000 \\
\hline $\mathrm{Ar}-1570$ & $\mathbf{N}$ & 13,000 & 20 & 13,000 & 80 & 39,000 & 20 & 13,000 & 1280 & 39,000 \\
\hline PI-30L & 40 & 162 & 80 & 4,374 & 320 & 4,374 & 20 & 162 & 1280 & 39,000 \\
\hline
\end{tabular}

${ }^{a}$ Titers are expressed as the reciprocal of the highest antiserum dilution at which one-half of the spiroplasmas are free and motile and one-half are deformed.

${ }^{b}$ Reciprocal of the highest antiserum dilution inhibiting glucose fermentation.

${ }^{c} \mathrm{~N}$, DF titer of less than $1: 20$.

\section{DISCUSSION}

In taxonomic studies of spiroplasmas, serological tests should be performed first. The DF test is very convenient and provides reliable information about interstrain relationships. MI tests usually confirm the data of DF tests but also provide additional sensitivity. In our study, these tests showed that the strains from Savoy are much more closely related to each other than to the strains from other insects in the United States and could represent a single subgroup. Among the New World strains, ANP and AEF-2 were similar or identical. Strains CC-1, MQ-6, CB-1 and ANP could not be subdivided clearly into subgroups on the basis of serological tests.
PAGE analysis of proteins is also an important technique in spiroplasma classification. Analyses of protein profiles of the strains of the subgroups of group I spiroplasmas agree well with serological analyses (15). In our study, also, the data obtained by PAGE analysis agreed with those obtained from serological studies.

Although serological techniques and one-dimensional PAGE of proteins were in good agreement, it was not possible to subdivide group XVI unequivocally into subgroups by these tests alone. We therefore selected five strains that appeared to have major differences in their serological and PAGE patterns and compared their genomes by three additional procedures: (i) determination of $\mathrm{G}+\mathrm{C}$

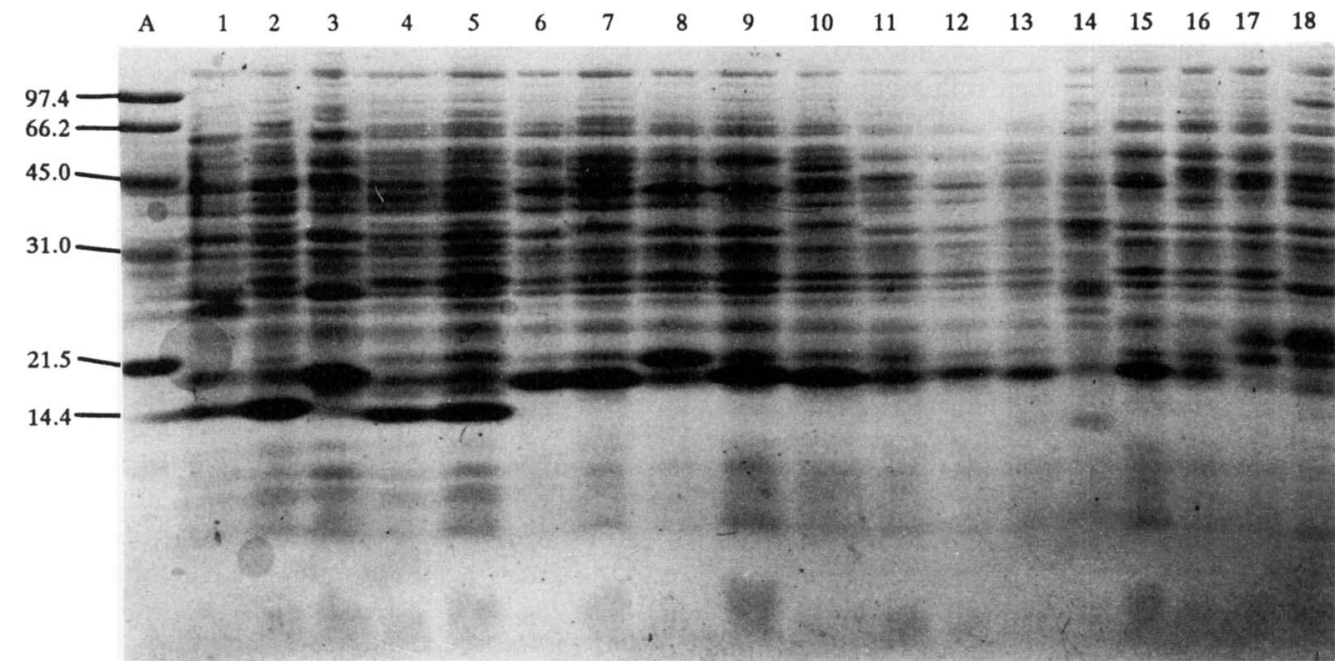

FIG. 1. SDS-PAGE of spiroplasmal proteins of group XVI. Lanes: A, Protein standard (Bio-Rad) containing phosphorylase $b$ (97.4 kDa), bovine serum albumin $(66.2 \mathrm{kDa})$, ovalbumin $(45 \mathrm{kDa})$, carbonic anhydrase $(31 \mathrm{kDa})$, trypsin inhibitor $(21.5 \mathrm{kDa})$, and lysozyme $(14.4 \mathrm{kDa})$; 1, S. cantharicola CC-1 (ATCC 43207) (reference strain); 2, CB-1; 3, MQ-6; 4, AEF-2; 5, ANP; 6, Ar-1357; 7, Ar-1528; 8, Ar-1531; 9, Ar-1537; 10, Ar-1546; 11, Ar-1548; 12, Ar-1549; 13, Ar-1569; 14, Ar-1550; 15, Ar-1566; 16, Ar-1567; 17, Ar-1570; 18, PI-30L. 
TABLE 3. G+C content of DNA of group XVI spiroplasmas

\begin{tabular}{lcc}
\hline \multirow{2}{*}{ Strain } & \multicolumn{2}{c}{ G+C content (mol\%) determined from: } \\
\cline { 2 - 3 } & $\begin{array}{c}\text { Buoyant density } \\
\text { (mean) }\end{array}$ & $\begin{array}{c}\text { Melting temperature } \\
\text { (mean) }\end{array}$ \\
\hline CC-1 & 26.6 & 25.4 \\
MQ-6 & ND $^{a}$ & 26.5 \\
CB-1 & 25.8 & 25.3 \\
ANP & ND & 26.3 \\
AEF-2 & ND & ND \\
Ar-1357 & 26.4 & 25.9 \\
Ar-1528 & 27.4 & 27.0 \\
Ar-1531 & 26.7 & 25.0 \\
Ar-1537 & 26.3 & 26.0 \\
Ar-1546 & 26.5 & 25.6 \\
Ar-1548 & 26.0 & 25.3 \\
Ar-1549 & 25.8 & 26.0 \\
Ar-1550 & 26.4 & 25.0 \\
Ar-1567 & 26.6 & 26.0 \\
\hline
\end{tabular}

${ }^{a}$ ND, not done.

content, (ii) DNA-DNA hybridization, and (iii) hydrolysis by restriction endonucleases.

The determination of the $\mathrm{G}+\mathrm{C}$ content of DNA is a recommended procedure for group classification $(18,20,22)$. Spiroplasma strains belonging to the same group almost always have identical $\mathrm{G}+\mathrm{C}$ contents of their DNAs (24). In our study, we found that the DNAs of 13 group XVI strains had a $\mathrm{G}+\mathrm{C}$ content of $(26 \pm 1) \mathrm{mol} \%$.

DNA-DNA hybridization, a technique that is routinely used to evaluate homologous sequences among related DNAs, has become a useful procedure for spiroplasma classification (22). DNA-DNA hybridizations between or among intergroup strains should show no homology (23). Clusters of strains that form subgroups show high levels of intragroup homology (approximately 90\%), whereas intersubgroup homology may range between 10 and $80 \%$. Subgroups that have $70 \%$ or less DNA-DNA homology with other subgroups within the same group are eligible for elevation to species status (10).

DNA-DNA hybridization has been used, in part, to subdivide group I spiroplasmas into eight subgroups. In this grouping, the hybridization data were in close accord with the serological data (2). On the other hand, DNA-DNA hybridization between strains of group IV revealed (1) that all strains had DNA homologies in excess of $75 \%$ and that this group could not be subdivided into different subgroups as had been previously proposed by using serological techniques (14). With group XVI, DNA-DNA hybridization data have led us to conclude that CC-1 and MQ-6 strains are very

TABLE 4. Percentages of hybridization between labeled DNA from strain CC-1 and nonlabeled DNA of strains CB-1, MQ-6, ANP, and AR-1357

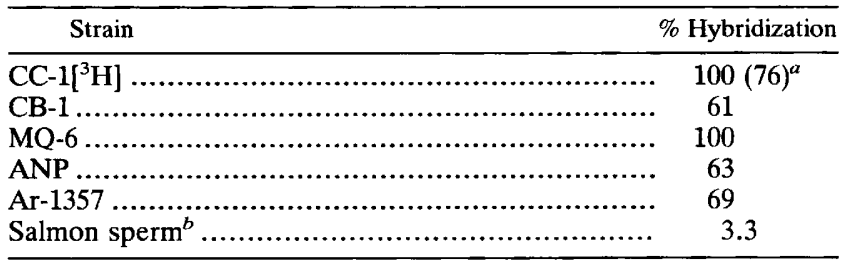

${ }^{a}$ The number in parentheses represents the actual hybridization in the homologous reaction, which was normalized to $100 \%$.

${ }^{b}$ Negative control.

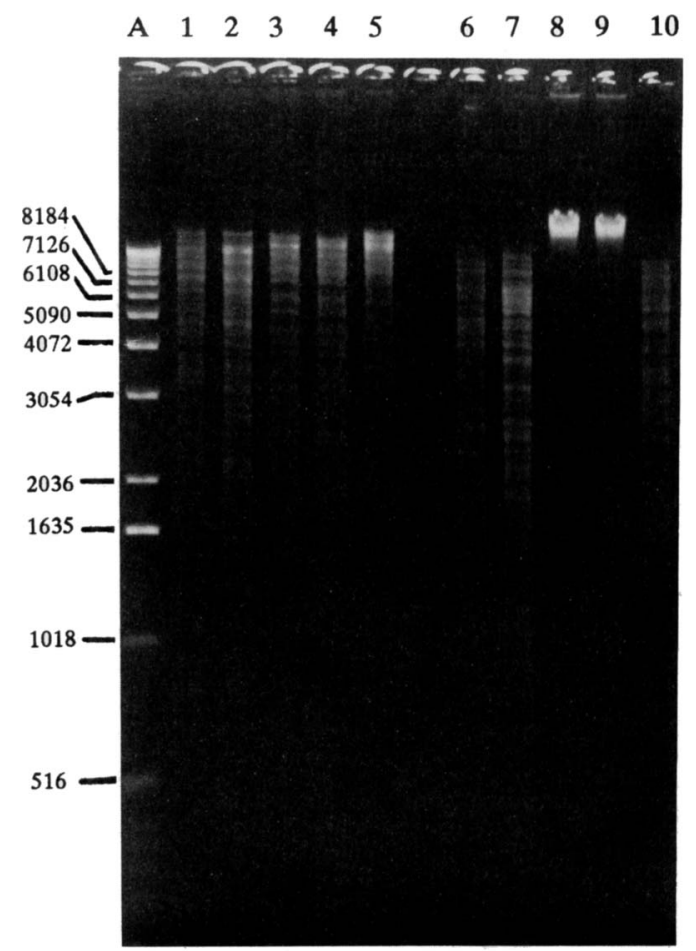

FIG. 2. DNA patterns of strains CC-1, MQ-6, CB-1, ANP, and Ar-1357 hydrolyzed by EcoRI (lanes 1 to 5) and HindIII (lanes 6 to 10) restriction enzymes by $1 \%$ agarose gel electrophoresis. Lanes: A, 1-kbp ladder (GIBCO-Bethesda Research Laboratories); 1, CC-1; 2, MQ-6; 3, CB-1; 4, ANP; 5, Ar-1357; 6, CC-1; 7, MQ-6; 8, CB-1; 9, ANP; 10, Ar-1357.

similar (the homology of their DNA is $100 \%$ ) and, on the basis of similar PAGE protein patterns and restriction enzyme profiles, can be placed in the same subgroup. Strains CB-1, ANP, and Ar- 1357 would constitute another subgroup because the homology between their DNA and CC-1 DNA is less than $70 \%(61,63$, and $69 \%$, respectively). However, a number of factors served to differentiate Ar-1357 and the other strains isolated in France from the four strains isolated from insects in the United States. (i) They are geographically separated. (ii) With the exception of one plant-derived strain (PI-30L), all the French strains were isolated from various species of mosquitoes, suggesting a commonality in their ecology. (iii) We observed close uniformity in the PAGE protein patterns of the French strains versus the four U.S. strains. (iv) The EcoRI- and HindIII-restricted DNA banding patterns of Ar-1357 are strikingly different from those produced by the four U.S. strains. The New World strains formed two related clusters: CC- 1 and MQ-6 and CB-1 and ANP.

Comparative analysis of all our data suggests a classification of spiroplasma group XVI into the following three subgroups: (i) subgroup XVI-1, comprising strains CC-1 and MQ-6; (ii) subgroup XVI-2, comprising strains CB-1, ANP, and AEF-2; and (iii) subgroup XVI-3, comprising strains Ar-1357 and all other strains from Savoy.

Strain CC-1 (ATCC 43207), the type species of $S$. cantharicola, is the representative strain of subgroup XVI-1, strain CB-1 (ATCC 43208) represents subgroup XVI-2, and strain Ar-1357 (ATCC 51126) represents subgroup XVI-3. 


\section{ACKNOWLEDGMENTS}

Part of this work was done in the Department of Anatomical Sciences, Health Sciences Center, State University of New York, Stony Brook, while M.L.A. was a Visiting Assistant Professor in the laboratory of D.L.W. Also, a portion of this work was done in the Department of Biochemistry, University of Medicine, Brest, and the Laboratory of Cellular and Molecular Biology, Villenave d'Ornon, France.

\section{REFERENCES}

1. Bové, J. M., P. Carle, M. Garnier, F. Laigret, J. Renaudin, and C. Saillard. 1989. Molecular and cellular biology of spiroplasmas, p. 243-364. In R. F. Whitcomb and J. G. Tully (ed.), The mycoplasmas, vol. 5. Academic Press, Inc., New York.

2. Bové, J. M., C. Mouches, P. Carle-Junca, J. R. Degorce-Dumas, J. G. Tully, and R. F. Whitcomb. 1983. Spiroplasmas of group I: the Spiroplasma citri cluster. Yale. J. Biol. Med. 56:573-582.

3. Carle, P., C. Saillard, and J. M. Bové. 1983. Determination of guanine-plus-cytosine content of DNA. Methods Mycoplasmol. 1:301-308.

4. Chastel, C., B. Devau, A. M. Simitzis-Le Flohic, R. Gruffaz, G. Kerdraon, and B. Gilot. 1987. Mosquito spiroplasmas from France and their ecology. Isr. J. Med. Sci. 23:683-686.

5. Chastel, C., B. Gilot, F. Le Goff, R. Gruffaz, and M. L. Abalain-Colloc. 1985. Isolement de spiroplasmes en France (Savoie, Alpes du Nord) à partir de moustiques du genre Aedes. C.R. Acad. Sci. 300:261-266.

6. Clark, T. B. 1982 . Spiroplasmas: diversity of arthropod reservoirs and host-parasite relationships. Science 217:57-59.

7. Daniels, M. J., D. B. Archer, M. A. Stephens, R. Townsend, J. M. Longland, and J. Best. 1980. Comparison of spiroplasmas by polyacrylamide gel electrophoresis of cell proteins. Curr. Microbiol. 4:377-380.

8. Degorce-Dumas, J. R., B. Ricard, and J. M. Bové. 1983. Hybridization between mycoplasma DNAs. Methods Mycoplasmol. 1:319-325.

9. Guo, J. H., T. A. Chen, R. F. Whitcomb, D. L. Rose, J. G. Tully, D. L. Williamson, X. D. Ye, and Y. X. Chen. 1990. Spiroplasma chinense sp. nov. from flowers of Calystegia hederaceae in China. Int. J. Syst. Bacteriol. 40:421-425.

10. International Committee on Systematic Bacteriology Subcommittee on the Taxonomy of Mollicutes. 1984. Minutes of interim meeting, 30 August and 6 September 1982, Tokyo, Japan. Int. J. Syst. Bacteriol. 34:361-365.

11. Hackett, K. J., R. F. Whitcomb, J. G. Tully, D. L. Rose, P. Carle, J. M. Bové, R. B. Henegar, T. B. Clark, E. A. Clark, M. Konai, J. R. Adams, and D. L. Williamson. 1993. Spiroplasma insolitum sp. nov., a new species of group I spiroplasma with an unusual DNA base composition. Int. J. Syst. Bacteriol. 43:272277.

12. Junca, P., C. Saillard, J. G. Tully, O. Garcia-Jurado, J. R. Degorce-Dumas, C. Mouches, J. C. Vignault, R. Vogel, R. McCoy, R. Whitcomb, D. Williamson, J. Latrille, and J. M. Bové. 1980. Caractérisation de spiroplasmes isolés d'insectes et de fleurs de France continentale, de Corse et du Maroc: proposition pour une classification. C.R. Acad. Sci. 290:12091212.

13. Konai, M., E. A. Clark, and R. F. Whitcomb. 1992. Temperature ranges and optima of spiroplasmas, p. 137. In Proceedings of the 9th International Congress of the International Organization for Mycoplasmology, Ames, Iowa, 2 to 7 August 1992.

14. Mouches, C., J. M. Bové, J. Albisetti, T. B. Clark, and J. G. Tully. 1982. A spiroplasma of serogroup IV causes a Maydisease-like disorder of honeybees in southwestern France. Microbiol. Ecol. 8:387-399.

15. Mouches, C., A. Menara, J. G. Tully, R. F. Whitcomb, and J. M. Bové. 1979. Characterization of spiroplasmas by one- and twodimensional protein analysis on polyacrylamide slab gel. Curr. Microbiol. 2:69-74.

16. Saglio, P., M. Lhospital, D. Lafièche, G. Dupont, J. M. Bové, J. G. Tully, and E. A. Freundt. 1973. Spiroplasma citri, gen. and sp. n.: a mycoplasma-like organism associated with "stubborn" disease of citrus. Int. J. Syst. Bacteriol. 23:191-204.

17. Shaikh, A. A., W. E. Johnson, C. Stevens, and A. Y. Tang. 1987. The isolation of spiroplasmas from mosquitoes in Macon County, Alabama. J. Am. Mosq. Control Assoc. 3:289-295.

18. Tully, J. G., D. L. Rose, E. Clark, P. Carle, J. M. Bové, R. B. Henegar, R. F. Whitcomb, D. E. Colflesh, and D. L. Williamson. 1987. Revised group classification of the genus Spiroplasma (class Mollicutes), with proposed new groups XII through XXIII. Int. J. Syst. Bacteriol. 37:357-364.

19. Whitcomb, R. F. 1983. Culture medium for spiroplasmas. Methods Mycoplasmol. 1:147-158.

20. Whitcomb, R. F., J. M. Bové, T. A. Chen, J. G. Tully, and D. L. Williamson. 1987. Proposed criteria for an interim serogroup classification for members of the genus Spiroplasma (class Mollicutes). Int. J. Syst. Bacteriol. 37:82-84.

21. Whitcomb, R. F., C. Chastel, M. L. Abalain-Colloc, C. Stevens, J. G. Tully, D. L. Rose, P. Carle, J. M. Bové, R. B. Henegar, K. J. Hackett, T. B. Clark, M. Konai, and D. L. Williamson. Spiroplasma cantharicola sp. nov., a new species from cantharid beetles (Coleoptera: Cantharidae). Submitted for publication.

22. Whitcomb, R. F., J. G. Tully, T. B. Clark, D. L. Williamson, and J. M. Bové. 1982. Revised serological classification of spiroplasmas, new provisional groups and recommendations for serotyping of isolates. Curr. Microbiol. 7:291-296.

23. Whitcomb, R. F., D. L. Williamson, J. M. Bové, J. G. Tully, K. J. Hackett, G. E. Gasparich, and M.-L. Abalain-Colloc. Unpublished data.

24. Williamson, D. L., J. G. Tully, and R. F. Whitcomb. 1989. The genus Spiroplasma, p. 71-109. In J. G. Tully and R. F. Whitcomb (ed.), The mycoplasmas, vol. 5. Academic Press, Inc., New York.

25. Williamson, D. L., and R. F. Whitcomb. 1983. Special serological tests for spiroplasma identification. Methods Mycoplasmol. 2:249-259.

26. Williamson, D. L., R. F. Whitcomb, and J. G. Tully. 1978. The spiroplasma deformation test, a new serological method. Curr. Microbiol. 1:203-207. 